\title{
Effets de la couleur des cheveux sur l'incorporation de drogues dans les cheveux humains
}

\author{
Effects of hair color on the drug \\ incorporation into human hair
}

Michaël UHL*, Frank SCHEUFLER

Bayerisches Landeskriminalamt, München - Germany

*Corresponding Author: Michaël UHL, Bayerisches Landeskriminalamt, Maillingerstr. 15 - 80636 München - Germany

(Reçu le 7 novembre 2005 ; accepté le 17 décembre 2005)

\section{RÉSUMÉ}

La couleur naturelle des cheveux est déterminée par les granules de pigments contenus dans la mèche. Les mélanosomes sont les pigments du cheveu. Ce sont des granules denses de mélanine, des chaînes d'indoles polymériques et de protéines associées à la mélanine. La couleur des cheveux dépend de la taille, du type, du nombre et de la distribution de ces granules. Il y a deux classes de pigments de mélanine dans les cheveux: les eumélanines, qui vont du brun foncé au noir; et les phéomélanines qui vont du rouge au jaune.

Plusieurs études in vitro et in vivo ont examiné l'influence de la pigmentation sur l'incorporation de différents stupéfiants organiques dans les cheveux humains et animales. Différentes approches et exposés montrent que la pigmentation/concentration de stupéfiants est un sujet complexe. Des résultats de ces études sont présentés dans cet article pour illustrer quelques points d'intérêt particuliers.

Le but de ces études était d'élucider la possible différence du taux d'incorporation en fonction de la mélanine. La fixation de grande variété de stupéfiants a été examinée : médicaments thérapeutiques, stupéfiants comme l'héroüne, la cocaïne, les amphétamines, les métabolites de drogues comme la $N$-acétylamphétamine et comme composés modèles, des colorants cationiques et anioniques. Dans quelques études, ce sont des concentrations de stupéfiants administrés aux personnes qui ont été déterminées, dans d'autres investigations, c'est la mélanine synthétique utilisée. Selon ces études,

\section{SUMMARY}

The natural color of hair is determined by pigment granules in the hair shaft. The pigment in hair is present as melanosomes. Melanosomes are dense granules of melanin, polymeric indole rings, and melanin-associated proteins. The color of hair depends on the size, type, number and distribution of the granules. There are two classes of melanin pigments in hair: eumelanins, which are dark brown to black and pheomelanins, which are red to yellow.

Several in vitro and in vivo studies scrutinized the influence of pigmentation and the deposition of different organic analytes in human hair as well as in animal hair:

Different approaches and statements point out the complex topic of pigmentation/ drug concentration. Some results of these studies will be presented in this paper to illustrate particular points of interest. The purpose of these studies was to elucidate, if there is a difference in incorporation rate as a function to melanin. The binding of a wide variety of drugs has been examined: therapeutic drugs, drugs of abuse like heroin, cocaine, amphetamines, metabolites of drugs like benzoylecgonine, modified drugs like $N$-acetylamphetamine and, as model compounds, cationic and anionic dyes. In some studies concentrations of drugs administered to individuals were determined, in some investigations synthetic melanin was used.

According to these studies, basic analytes being positively charged at physiologic $p H$.e.g. cocaine, amphetamine, 
des stupéfiants alcalins, positivement chargés à $p H$ physiologique (par exemple de la cocaüne, de l'amphétamine, de la codéine, de l'amitryptiline), ont montré une préférence d'incorporation dans les cheveux pigmentés par rapport aux non pigmentés.

Il a été démontré que des stupéfiants neutres et acides et des métabolites ( $N$-acétyl-amphétamine, 9-carboxy-THC, benzolecgonine), qui interagissent par des forces de Van der Waals faibles, ont une faible ou aucune affinité à la mélanine.

Utiliser des méthodes appropriées de préparation et d'extraction d'échantillon peut aider à réduire les effets décrits. Dans une étude avec de la codéine, la normalisation de la concentration du stupéfiant avec de la mélanine a aidé à minimaliser les différences observées selon la couleur des cheveux.

Cependant, les études statistiques n'ont trouvé que peu de preuve de la seule influence de la couleur des cheveux sur la fixation sélective des stupéfiants.

De même, les données des laboratoires du Bayerisches Landeskriminalamt (Bureau d'Investigations Criminelles de Bavière) entre janvier 2004 et août 2005 n'ont pas montré de lien entre la couleur foncée des cheveux et les concentrations de cannabinoüdes, cocaïne, amphétamine et opiacés trouvées dans les cheveux.

En principe, les effets potentiels de la pigmentation naturelle sur l'incorporation de stupéfiants dans les cheveux devraient être considérés comme un paramètre important dans l'évaluation des résultats analytiques.

\section{Introduction}

In recent years there have been several studies assessing the linkage between the color of hair and the concentration of drugs determined in hair. The natural color of human hair is determined by pigment granules in the hair shaft, which are also called melanosomes. Hair melanins are polymers produced in melanosomes (1), the distinctive particles which are the product of melanocytes. The color of hair depends on the size, type, number and distribution of the melanosomes in the hair shaft.

There are two classes of melanin pigments in hair (Figure 1): Dark brown to black colored eumelanins are composed basically of 5,6-dihydroxyindole units and 5,6-dihydroxyindole-2-carboxylic acid. They are insoluble in acids and alkali. A biosynthetic combination of tyrosine and cysteine leads finally to reddish yellow pheomelanins which are soluble in dilute alkali.

With a concentration ratio of $0,08 \%-2,0 \%$ (Table I), melanin is a minor component of hair. The main components of human hair consist of approximately $65 \%$ to $95 \%$ proteins, depending on its moisture content (up to $32 \%$ by weight). The remaining constituents are water, lipids, pigment and trace elements. The main amino acids found in human hair are half-cystine, serine, glutamic acid, proline, threonine, arginine, leucine (4).

Hair may be thought as an ion exchange resin (5). Basic drugs are positively charged at physiologic $\mathrm{pH}$. An ionic codeine, amitryptiline) showed a preference for incorporation into pigmented versus nonpigmented hair. It was documented that neutral and acidic drugs and metabolites ( $N$ acetyl-amphetamine, 9-Carboxy-THC, benzoylecgonine) which interact only by weak van der Waals forces showed a low or no affinity to melanin.

Using suitable methods of sample preparation and extraction can be helpful to reduce the described effects essentially. In a study with codeine, normalization of the drug concentration with melanin concentration was useful to minimize the hair color differences observed.

However, statistical examinations found little evidence of a pattern attributable to hair color bias alone or selective binding of drugs to hair of a particular color.

Likewise, data collected from the labs of the Bayerisches Landeskriminalamt (Bavarian State Bureau of Investigation) in the period January 2004 to August 2005 did not find any prevalence of dark hair color and concentrations of cannabinoids, cocaine, amphetamine and opiates determined in hair.

In principle, the potential effects of natural pigmentation on drug incorporation into hair should be considered as important parameter in the evaluation of analytical findings.

attraction occurs between the polyanionic melanin or proteins in hair and the cationic (protonated) drug (6). The binding of less polar drugs to other hair components i.e. lipids arises via van der Waals interactions.

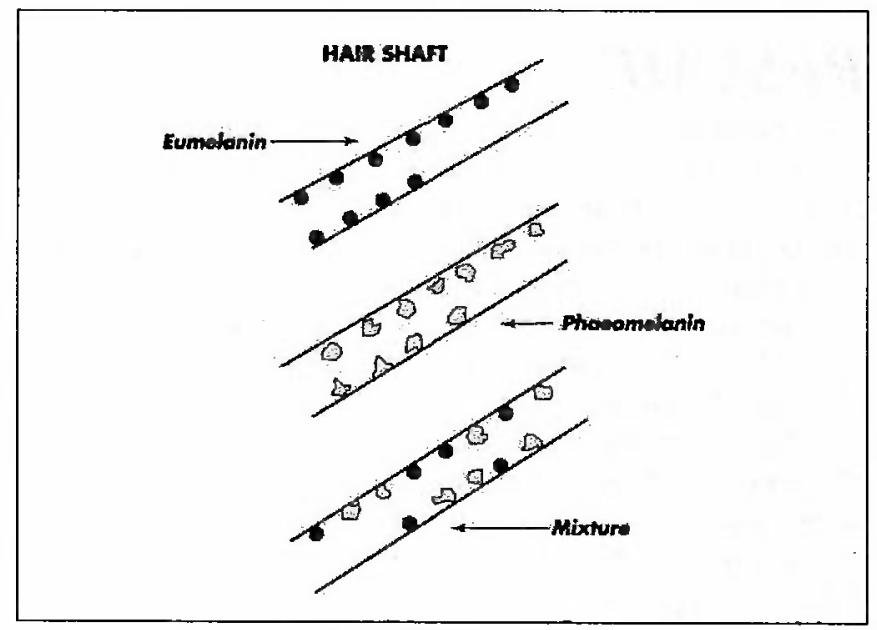

Figure 1 : Two main types of melanin: eumelanin and pheomelanin (2).

Table I: Melanin content in the hair of Caucasian subjects (3).

\begin{tabular}{|c|ccc|}
\hline & $\begin{array}{c}\text { Samples } \\
(\mathrm{n})\end{array}$ & $\begin{array}{c}\text { Total melanin } \\
(\mu \mathrm{g} / \mathrm{mg} \text { hair })\end{array}$ & $\begin{array}{c}\text { Median } \\
(\mu \mathrm{g} / \mathrm{mg} \text { hair })\end{array}$ \\
\hline Light blond & 20 & $0.8-2.4$ & 2 \\
Medium blond & 15 & $1.2-5.0$ & 3 \\
Reddish & 5 & $3.8-5.7$ & 4 \\
Brown & 15 & $3.3-11.5$ & 5.7 \\
Black & 10 & $8.0-20.0$ & 12 \\
\hline
\end{tabular}




\section{Discussion}

Different approaches to cope with the issue of hair pigmentation and drug concentration have been reported in literature. The present paper reviews some characteristic publications devoted to hair color as a potential biasing factor in hair analysis.

These studies will be supplemented by a collection of data selected from 383 relevant forensic reports submitted by the Bavarian State Bureau Investigation (BLKA).

\section{Studies in Literature}

The effect of hair color on the incorporation of codeine into human hair (7)

Male and female Caucasians with black, brown, blond, or red hair and non-Caucasians with black hair were administered with oral doses of codeine phosphate syrup to study the incorporated substance as a function of melanin concentration ( $30 \mathrm{mg}$ codeine, $3 \mathrm{x}$ per day, 5 days).

A strong relationship between the hair concentrations of codeine and melanin was observed. Normalization of the codeine concentration with the melanin concentration reduced the hair color differences observed.

Incorporation of selegiline metabolites into hair after oral selegiline intake (8)

The study on 10 subjects was performed to investigate the relationship between melanin content of hair and the incorporation of selegiline metabolites into hair after a single oral dose of selegiline. The results show strong positive exponential relationships between melanin and the metabolites (amphetamine, methamphetamine). The authors conclude that the incorporation closely relates to the melanin content.

Amphetamine and $\mathrm{N}$-acetylamphetamine incorporation into hair: an investigation of the potential role of drug basicity in hair color bias (9)

Long-Evans rats were dosed with amphetamine (Amph) or its non-basic analogue $\mathrm{N}$-acetylamphetamine ( $N$-AcAmph) and their hair evaluated for drug content via LC-MS/MS.

Black hair from rats dosed with Amph was found to contain $6.44 \pm 1.31$ (SD) ng Amph/mg hair. White hair from the same rats contained $2.04 \pm 0.58 \mathrm{ng} \mathrm{Amph} / \mathrm{mg}$ hair. No difference was found between black hair $(0.87$ $\pm 0.08 \mathrm{ng} N$-AcAmph/mg hair) and white hair $(0.83 \pm$ $0.15 \mathrm{ng} N$-AcAmph $/ \mathrm{mg}$ hair) from rats dosed with $N$ AcAmph.

Cocaine, benzoylecgonine, amphetamine, and n-acetylamphetamine binding to melanin subtypes (10)

Experiments have been performed to document the in vitro binding of above drugs to synthetic melanin sub- types. The melanins included in this study are two black eumelanin subtypes, a reddish-brown pheomelanin, and two mixed eu-/pheomelanin copolymers. The results indicate that the basic drugs cocaine and amphetamine bind to eumelanins and mixed eu-/pheomelanins to varying degrees, but not to pure pheomelanin. $\mathrm{BE}$ and N-AcAmph do not bind to any type of melanin. Amphetamine binding to synthetic melanin and scatchard analysis of binding data (11)

There are no structural disparities in hair of different colors other than the type and content of melanin present. This investigation focuses on synthetic eumelanin as a site for drug interaction using amphetamine.

As the molecular weight of melanin is unknown, the number of binding sites could not be calculated directly. Hence the ratio of the number of (moles of drug bound and the dry weight of melanin in $\mu \mathrm{g}$ was considered. Equilibrium was reached when approximately $32 \%$ of the drug was bound to melanin. The study proves that amphetamine binds to synthetic eumelanin in vitro.

Hair analysis for drugs of abuse. Hair color and race differentials or systematic differences in drug preferences? (12)

They examined a total of 2000 randomly selected samples; 500 negative hair samples and 500 positive samples for each of three drug classes: cannabinoids, cocaine, and amphetamine. They also evaluated ethnic/racial factors in relation to positive urine analysis for various ethnic/racial groups. There was little evidence of a pattern attributable to hair color bias alone or selective binding of drugs to hair of a particular color. Likewise, there was no discernible pattern associated with race or ethnicity that would lend support a "race effect" in drug analysis.

Effect of pigmentation on the drug deposition in hair of grey-haired subjects (13)

The hair samples of 15 grey-haired patients with a permanent medical treatment by amitriptyline (concentration ratio: white hair/pigmented hair $=0.18-0.88$ ), carbamazepine, chlorprothixene, diclofenac (white/pigmented $=0.62$ ), doxepine, indomethacine, maprotiline or metoclopramide (white/pigmented $=0.09$ ), or with a chronic heroin and cocaine abuse (cocaine: white/pigmented $=0.87$, benzoylecgonine: white/pigmented $=$ 1.00) were separated into white and pigmented fibers and both fractions were independently investigated by GC-MS. The drugs were found in pigmented fibers as well as in white fibers, but the concentrations in the white fibers were smaller than in the pigmented ones for the most of the samples investigated.

The incorporation of dyes into hair as a model for drug binding (14)

The binding of charged substances from external 
aqueous media to hair has been investigated through the use of fluorescence microscopy. 11 hair samples, reflecting various ethnic groups and cosmetic treatments, were tested. Rhodamine $6 \mathrm{G}$, a cationic dye representative of drugs such as cocaine and opiates, showed incorporation throughout the hair of all samples except one. In contrast fluorescein, an anionic dye representative of drugs such as 9-carboxy-THC, was not readily incorporated.

Assessing the potential of a "color effect" for hair analysis of 1I-nor-9-carboxy- $\Delta^{9}$-tetrahydrocannabinol: Analysis of large sample of hair specimens(15)

The study evaluates the possible effect of hair color on the concentration of 11-nor-9-carboxy- $\Delta^{9}$-tetrahydrocannabinol (9-carboxy-THC) in human hair. The analysis is based on 3,886 positive specimens drawn from a universe of approximately 80,000 specimens of scalp hair.

Analysis of variance of color categorization by 9 -carboxy-THC concentration shows that 9-carboxy-THC concentration does not have a significant association with hair color.

\section{Statistical examination of hair color as a potential biasing factor in hair analysis (16)}

They review eight different data sets in their paper for the purpose of assessing the possibility that reported color of hair can produce a systematic bias in the interpretation of hair assays. They used two major statistical techniques for assessing significance. The analysis of this data fails to discern a significant color effect. But it is their view that color may play a role in the accumulation of drugs in hair, however it is likely to account for only a very small part of the complex process of drug accumulation.

\section{Authentic Case}

\section{Detection of metoprolol (17)}

A hair sample was taken from a grey-haired person being a patient with high blood pressure. He was under medication of metoprolol (Beloc $\circledast$ ) with a daily dosage of $20 \mathrm{mg}$ (as $50 \mathrm{mg}$ metoprololtartrate). The concentration of metoprolol detected in white hair was 0.64 $\mathrm{ng} / \mathrm{mg}$ hair, in black hair $1.92 \mathrm{ng} / \mathrm{mg}$ hair.

\section{Data collected from the labs of the Bavarian State} Bureau of Investigation (BLKA)

The BLKA is exclusively responsible for criminal acts. It is not responsible for civil and administrative law cases and conducts no workplace testing.

The specimens are mostly taken from defendants (drug dealers, drug addicts, rapists), sometimes from victims of criminal acts.

The presented data is collected from 383 expert reports in the period January 2004 to August 2005. As shown in Figure 2 below, the majority of hair samples were taken from the head and sometimes it was necessary to test also nonhead hair.

The color of the hair samples examined by the BLKA is illustrated in Figure 3. $66 \%$ of the samples were natural brown hair, followed by blond hair with $18 \%$, and black hair with $9 \%$.

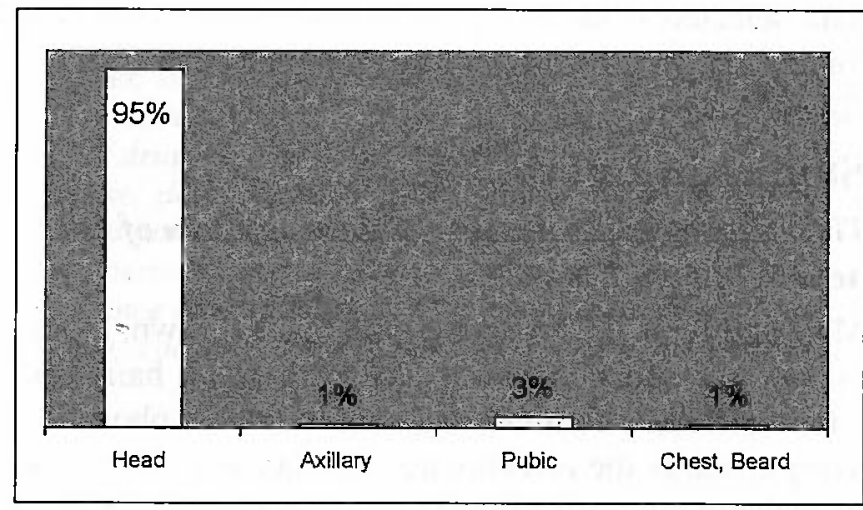

Figure 2: Type of hair samples examined by the BLKA.

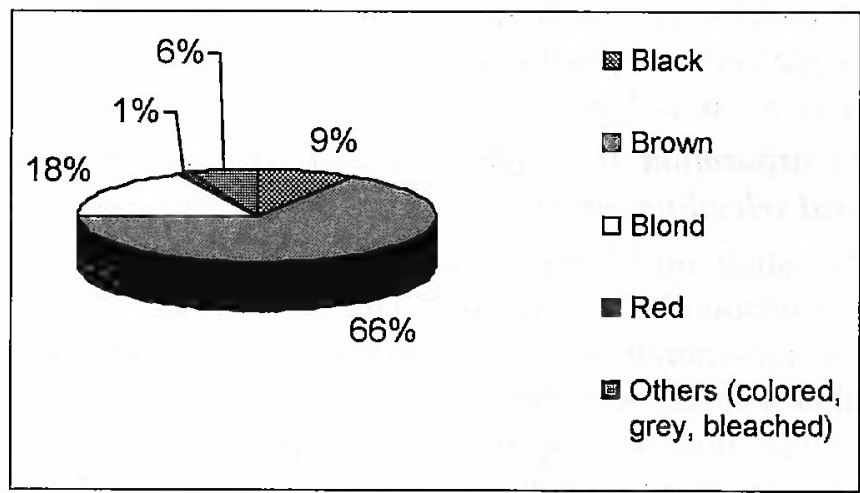

Figure 3 : Color of hair specimens examined by the BLKA.

The different drug classes detected in the hair specimens of the subjects are demonstrated in Figure $4.75 \%$ of hair specimens were found positive for cannabinoids (THC/CBN and/or 9-carboxy-THC), 44\% positive for cocaine (cocaine and at least one of the metabolites benzoylecgonine, norcocaine, cocaethylene).

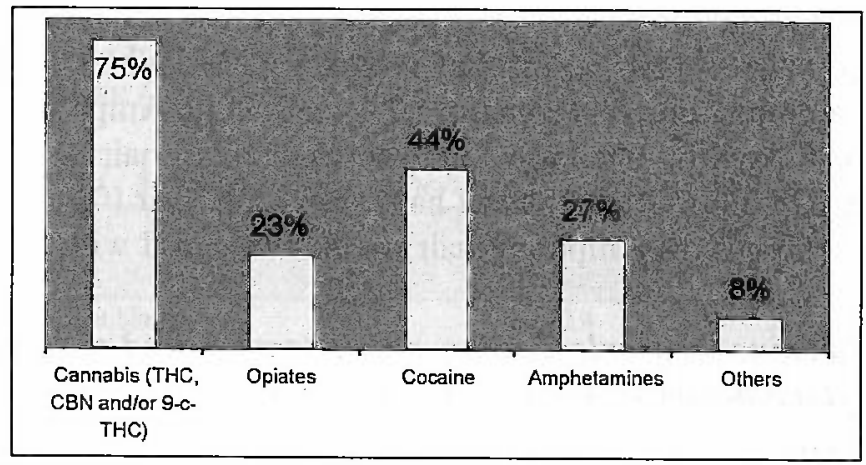

Figure $4:$ Type of drugs found in positive samples. 
The distribution of hair color in negative and positive hair samples is presented in Figure 5. Positive results were obtained for $85 \%$ of the brown hair, $88 \%$ of the black hair and $90 \%$ of the blond hair samples. These figures point out that there is no prevalence of dark colored hair to be tested positive compared to light colored hair. As illustrated in Figure 6, a specified drug class related distribution leads to the same conclusion.

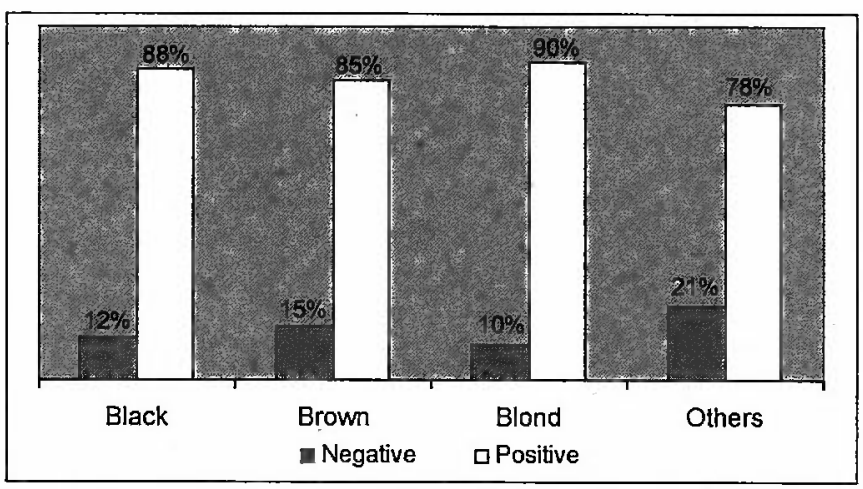

Figure 5 : Distribution of hair color in negative and positive samples.

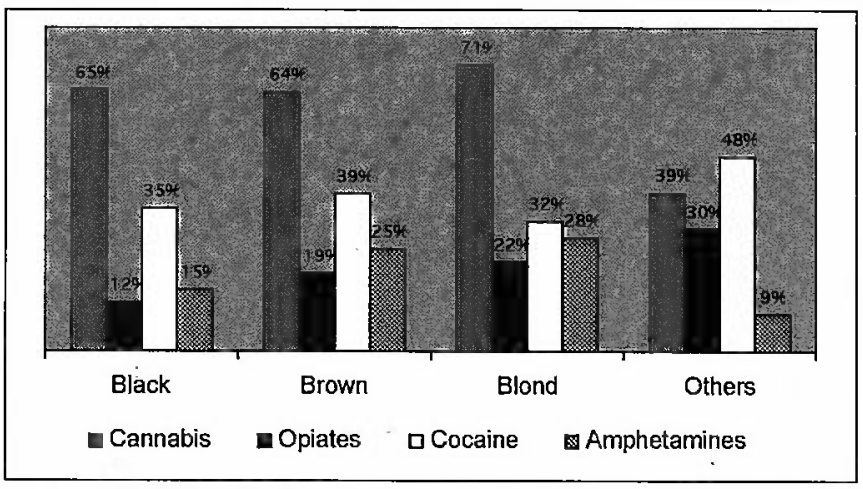

Figure 6 : Correlation between hair color and drug classes.

\section{Conclusion}

According to the cited studies, drugs found with higher melanin affinity are metoclopramide, codeine, amitryptiline, amphetamine, maprotiline, and cocaine. Drugs found with low melanin affinity are benzoylecgonine, $\mathrm{N}$-acetylamphetamine, and 9-carboxy-THC.

The outcome of these controlled studies and statistical examinations is the existence of a higher binding affinity of basic drugs to melanin.

If a person has more total eumelanin in hair is there a higher probability of a positive drug hair test? Are different cutoff concentrations necessary?

The normalization of drug concentration with the melanin concentration reduces the hair color difference. According to statistical examinations and our own data, there is no substantial "hair color bias".

\section{References}

1. K. Jimbow, T. B. Fitzpatrick, and W. C. Quevedo Jr. Formation, chemical composition and function of melanin pigments. In: J. Bereiter-Hahn, A. G. Matoltsy, and K S. Richards, ed. Biology of the Integument 2: Vertebrates. Berlin: Springer Verlag, 1986; 873-909.

2. Texas Collaborative for Teaching Excellence.

3. L. Pötsch, and K. Bender. Untersuchungen zu möglichen Mechanismen einer PCR-Henmung in Haarextrakten durch Melanine. Rechtsmedizin 11: 42-45 (2001).

4. C. R. Robbins. Chemical and physical behavior of human hair. Berlin: Springer Verlag, 1994; 55-87.

5. D. A. Kidwell, and D.L. Blank. Environmental Exposure The stumbling block of hair testing. In: P. Kintz, ed. Drug testing in hair. Boca Raton: CRC Press, 1996; 17-68.

6. D. E. Rollins, D.G. Wilkins, S.P. Gygi, M.H. Slawson, and P.R. Nagasawa. Testing for drugs of abuse in hair Experimental observations and indications for future research. Forensic Sci. Rev. 9: 23-36 (1997).

7. D. E. Rollins, D. G. Wilkins, G. G. Krueger, M. P. Augsburger, A. Mizuno, C. O`Neal, C. R. Borges, and M. $H$. Slawson. The effect of hair color on the incorporation of codeine into human hair. J. Anal. Toxicol. 27: 545-551 (2003).

8. R. Kronstrand, M. C. Andersson, J. Ahlner, and G. Larson. Incorporation of selegiline metabolites into hair after oral selegiline intake. J. Anal. Toxicol. 25: 594-601 (2001).

9. C. R. Borges, D. G. Wilkins, and D. E Rollins. Amphetamine and $\mathrm{N}$-acetylamphetamine incorporation into hair: an investigation of the potential role of drug basicity in hair color bias. J. Anal. Toxicol. 25: 221-227 (2001).

10. C. R. Borges, J. C. Roberts, D. G. Wilkins, and D. E. Rollins. Cocaine, benzoylecgonine, amphetamine, and nacetylamphetamine binding to melanin subtypes. J. Anal. Toxicol. 27: 125-134 (2003).

11. L. Gautam, K. S. Scott, and M. D. Cole. Amphetamine binding to synthetic melanin and scatchard analysis of binding data. J. Anal. Toxicol. 29: 339-344 (2005).

12. R. C. Kelly, T. Mieczkowski, S. A. Sweeney, and J. A. Bourland. Hair analysis for drugs of abuse. Hair color and race differentials or systematic differences in drug preferences? Forensic Sci. Int. 107: 63-86 (2000).

13. M. Rothe, F. Pragst, S. Thor, and J. Hunger.Effect of pigmentation on the drug deposition in hair of grey-haired subjects. Forensic Sci. Int. 84: 53-60 (1997).

14.S. F. DeLauder, and D.A. Kidwell. The incorporation of dyes into hair as a model for drug binding. Forensic Sci. Int. 107: 93-104 (2000).

15. T. Mieczkowski. Assessing the potential of a "color effect" for hair analysis of 11-nor-9-carboxy-(9-tetrahydrocannabinol: Analysis of large sample of hair specimens, Life Sci.; 74: 463-469 (2003).

16. T. Mieczkowski, and R. Newel. Statistical examination of hair color as a potential biasing factor in hair analysis. Forensic Sci. Int.107: 13-38 (2000).

17. M. Uh1. 6. Alpe-Adria-Pannonia Meeting. Veszprém, Hungary. Presentation 1997. 